\title{
Sodium Clearance Measurement
}

National Cancer Institute

\section{Source}

National Cancer Institute. Sodium Clearance Measurement. NCI Thesaurus. Code

C106568.

The determination of the amount of the sodium clearance in a sample. 